\title{
The beginnings of Hungarian lexicography. From the first glossaries to multilingual dictionaries
}

\author{
Emese Fazakas ${ }^{\star}$ \\ Faculty of Letters, "Babeș-Bolyai” University, Str. Horea 31, 400202 Cluj-Napoca, Romania
}

\section{Article info}

History:

Received September 15, 2021

Accepted October 5, 2021

Published December 12, 2021

Key words:

lexicography

glosses

nomenclatura

vocabularium

dictionary

\begin{abstract}
This study aims to present the beginnings of Hungarian lexicography, with a special focus on certain works that are closely connected with Transylvania. The early glossaries, starting with the $13^{\text {th }}$ century, are either marginal or interlinear. The only early source in which glossaries are intertextual, distinguished from the Latin text by underlining, is Sermones Dominicales, a compilation of sermons written in the first half of the $15^{\text {th }}$ century. The vocabularies and nomenclatures under analysis were elaborated between the $14^{\text {th }}$ century and the end of the $16^{\text {th }}$ century, most of them being based on lists of Latin words grouped according to semantic fields. The only work that was elaborated based on the Hungarian lexis is the Nomenclature from Schlägl, a copy dating from around 1405 of a document written a few decades before. Among these vocabularies there are some that could be regarded as the first attempts to elaborate specialized dictionaries. Starting with the $16^{\text {th }}$ century, several dictionaries in which the title-words are arranged alphabetically were identified. However, the early dictionaries are either unfinished or only partially preserved. The most representative dictionaries, mainly multilingual, were elaborated starting with the late $16^{\text {th }}$ century. Our presentation ends with József Benkö's botanical dictionaries, edited in 1783, which mark the beginnings of modern Hungarian lexicography.
\end{abstract}

\section{Introduction}

The aim of this study is to present the first attempts to elaborate vocabularies, bilingual and multilingual dictionaries, indispensable sources in the research on the development of lexicography and the diachronic analysis of the lexis. Moreover, glosses are also presented, as they are the earliest such attempts, although their main purpose was to understand a certain text written in a foreign language. Besides these glosseswhich were written even during the $16^{\text {th }}$ century-starting with the $14^{\text {th }}$ century we can already speak of vocabularies, namely bilingual nomenclatures, of which we shall select the most significant. One can rightfully state that modern Hungarian lexicography begins with these dictionaries-especially the multilingual ones-that were compiled starting with the second half of the $16^{\text {th }}$ century. The end of the $18^{\text {th }}$ century can be regarded as a threshold in Hungarian lexicography, since the year 1772 marks the beginning of a period in which the language reform was a priority for Hungarian scholars. Thus, starting with the early decades of the $19^{\text {th }}$ century, tens of dictionaries were compiled. Our presentation is limited to bilingual and multilingual lexicographic works and does not include explanatory dictionaries.

\section{The development of Hungarian lexicography}

In the light of the discovered linguistic sources, we can claim that lexicographic works were issued at the same time with the first religious texts. As they were aimed at practical purposes, either in order to understand a certain text or to learn and then teach a foreign language, vocabularies were gradually

^Email address: fazakasemese@gmail.com. 
elaborated, followed by dictionaries, as we know them today. We shall present the most representative such works issued between the $13^{\text {th }}$ and the $18^{\text {th }}$ century, which have contributed to the development of Hungarian lexicography. Although from a chronological perspective the groups presented below may overlap, we chose to organize them according to their characteristic rather than according to the chronological dimension, as this strategy allows us to point to the manner in which scholars progressed in their endeavours. The first works we present are thus the glosses, then vocabularies, and manuscript and printed nomenclatures, and finally the alphabetically arranged dictionaries.

\subsection{Glosses}

We cannot omit the presentation of few early glosses, as they represent important sources of lexicological and lexicographic research and constitute the first attempts to render the equivalents of certain Latin words or phrases in vernacular language. The glosses were written-as in Medieval Europe-either for a pedagogical purpose or for a better understanding of texts written in another language, Latin in this particular case.

The first glosses we know of, which include 11 Hungarian words, also known as the Oxford Glosses, were introduced in a Latin codex around the year 1230. The codex written by Petrus Comester, entitled Historie Scholastice, was elaborated for learning and interpretation of Biblical texts and was used for the education of students who attended Episcopal schools. The marginal glosses discovered by the archivist of the Central Library of Oxford University, Albinia de la Mare, were presented and analyzed in detail by Mezey $(1979,1981)$, further explanations being subsequently added by Büky (1984) and Benkő (1984). The Hungarian glosses refer to a series of objects or plants in use in the Hungarian Kingdom. For instance: "C rix-cis [!] est herba que in acquis crescit et manum incidit, quod dicitur in hungaria sas", "id est quibusdam spericis retinnaculis quibus ora uestium constringi solent, quod in hungarico dicitur güb [gumb]" (Mezey, 1981).

By the end of the $13^{\text {th }}$ century, around the year 1290, a Hungarian scholar mentions 4 conjugated verbs in a compilation of sermons written in Paris. The glosses were preserved in a codex owned by the Vatican library and are known as the Vatican Glosses (Gábriel, 1943).

The Glosses from Alba Iulia were written in the first decades of the $14^{\text {th }}$ century (around the year 1320) and are kept at Batthyaneum Library (R.III. 89, f. 50 $125^{\mathrm{r}}, 154^{\mathrm{r}}$ ). The codex discovered by Elemér Varjú in 1898 (see Varjú, 1899) contains 3 rhyming lines in Hungarian on the side of some Latin sermons, most likely written by Franciscans (Madas, 2009, p. 228-229).

One of the most famous old Hungarian manuscripts, currently kept at Teleki-Bolyai Library in TîrguMures, is the Koncz codex. The $14^{\text {th }}$ century Latin parchment book was discovered by the librarian of the Reformed College in Tîrgu-Mureș, József Koncz, in the second half of the $19^{\text {th }}$ century, in an outbuilding owned by the Rhédey family in Sîngeorgiu de Pădure. The librarian transported the codex at the College Library and in 1948 this patrimony was taken by the Teleki-Bolyai Library, where Elek Farczády and Attila Szabó T. identified some lines and a few glosses written in Hungarian (see Farczády \& Szabó T., 1957; Szabó T., 1957; Benkö, 1958). These coherent lines and 11 marginal glosses (known as the Lines and Glosses from $\mathrm{Tg}$-Mureș) were written in the early $15^{\text {th }}$ century. The text is a synthesis of some fragments from the Book of Kings in the Old Testament and contains a total of 55 Hungarian words.

From the second half of the $15^{\text {th }}$ century, there dates a collection of 123 sermons written by a Hungarian scholar, a manuscript kept at the Library of ELTE University in Budapest (Cod.Lat. 98). The author of the codex entitled Sermones Dominicales aimed at helping the clerics to compile sermons for the Hungarian church-goers, by inserting numerous Hungarian words and phrases into the Latin texts. These writings can be grouped in two categories: interlinear glosses in the case of pericopes and intertextual glosses in sermons written by the same hand, following their Latin correspondents and underlined in the text to be distinguished. The latter represent translations of certain phrases, of less known Latin words or of Latin words considered more difficult to understand (for instance, f. $230^{\text {va }}$ : "consubstantialis - állatban egy"; f. $130^{\mathrm{rb}}$ : “naturalis - természet szerint való, essentialis - állat szerinti”) or denoting powerful feelings 
(for instance the cries of Virgin Mary $131^{\mathrm{rb}}$ : “jaj nekem” 'Oh, me!', “Én egyetlen egy szerelmem” 'My only love'1) (Tóth, 2009a, p. 244-245). From a dialectal perspective, the author of the glosses belongs to the south-eastern area of the Hungarian Kingdom (nowadays the Baranya County) (see Mészöly, 1910; Zolnai, 1910; Tóth, 2009a).

From the $16^{\text {th }}$ century there are several glosses on the same topic: plant names, as well as names of animals and minerals. The Casanate Glosses dating from the early $16^{\text {th }}$ century, that were discovered at the Casanate library in Rome, are found in a medical lexicon containing entries arranged in alphabetical order and numerous pictures. Most title-words designate plants, animals and minerals, while the explanations focus on their medical use. The Hungarian glosses are placed on the upper part of 87 pictures of medicinal plants. Besides these, 7 Hungarian words are written on the sides of some medical prescriptions. The glosses belong to several authors: the first one added 44 names in the early $16^{\text {th }}$ century, 33 more were added by another author at the end of the $16^{\text {th }}$ century, whereas the others were added by 4 or 5 different hands at the beginning of the following century (Schönherr, 1904).

In the 1517 edition of the first encyclopædic work of natural sciences-Ortus Sanitatis-454 Hungarian names of plants, animals and minerals were inserted between 1520 and 1530. According to Ernyey \& Jakubovich (1915), the author of these glosses was a doctor.

Other two books containing hundreds of Hungarian glosses were presented and analyzed by Szabó T. $(1943,1958)$. The first is a natural sciences book written in Latin, entitled De herbis et simplicibus medicamentis. As the cover and the title-page are missing, it is practically impossible to establish the edition. It includes 400 glosses written around the end of the $16^{\text {th }}$ century which make reference solely to medicinal plants. The book, whose last owner was Sámuel Pataki, a doctor and professor at the Reformed College in Cluj between 1758 and 1784, contains several Hungarian glosses added in the $17^{\text {th }}$ and $18^{\text {th }}$ centuries, some even by the above-mentioned owner. The other book, edited in Marburg in 1543, is an edition of Discorides' De Medicinali Materia Libri Sex enriched with names of plants, medicines and animals in Greek, Latin, Hebrew and German by Ioannes Lonicerus. In this copy—which can be currently found at the Library of the Cluj Branch of the Romanian Academy-50 Hungarian names of plants were introduced around the end of the $16^{\text {th }}$ century. This book also contains several Hungarian notes dating from the $17^{\text {th }}$ and $18^{\text {th }}$ centuries. According to Szabó T. (1958), the authors of these glosses could not be identified.

The Glosses from Cluj can be found in a Latin-German dictionary edited in 1528. Nearly all the pages of the dictionary contain notes in Hungarian. Some of the glosses, around 800 words, are thought to date from about 1550, whereas the other group (approximately 3300 words) was introduced around the year 1577 by several authors who also added some corrections to the previous notes. The first hand is that of a person from the western region of the Hungarian Kingdom, while the subsequent corrections were performed by one or several people from the Trei Scaune area (Covasna region) (Pálfi, 1907).

The Glosses from Turda belong to a young author, Tamás Tordai, born in Turda in 1551. As a student in Cluj, between 1568 and 1573 he introduced several Hungarian names of objects, abstract notions, verbs and nouns related to the daily life of the peasants in the book entitled Cornucopie written by Perottus (1532 edition, Basel). On the back side of the cover there is also a list of Latin words with their Hungarian correspondents, but this list belongs to another author, who was not identified. After 1616, the new owner of the book, Benedek Nagyrákosi, added Hungarian glosses for several hundreds of Latin phrases, words (Viski, 1906).

\subsection{Vocabularia, nomenclatura}

Having a pedagogical purpose, the first vocabularia and nomenclatura are not structured alphabetically. Instead, the words are grouped according to certain topics and include mostly nouns. The very first vocabularia and nomenclatura are obviously manuscripts; the first printed lexicon, structured thematically, was

${ }^{1}$ Examples are rendered in the contemporary ortography, as they appear in Tóth (2009a). Further on, the examples are rendered as they appear in manuscripts or editions. 
written around 1533.

The ones that are of high interest for us were issued at the end of the $14^{\text {th }}$ century (the Nomenclature from Königsberg, the Nomenclature from Bistrița, and the Nomenclature from Schlägl) and seem to have the same source: a Latin-German vocabulary ${ }^{2}$ (Vízkelety, 2009). The Nomenclature from Königsberg, written between 1350 and 1380, comprises 159 Latin words and 100 Hungarian equivalents. They denominate family and kinship relations, the five senses, physical and mental traits, adjectives related to these traits, nouns related to diseases, clothes, tools, weapons, etc. (Melich, 1916). The original text of the Nomenclature from Bistrița was written between 1380 and 1390 based on the same Latin-German vocabulary; the 15 pages discovered at the end of the $19^{\text {th }}$ century are copies made sometimes around the year 1395or between 1380 and 1410 - by the same person (Gáldi, 1938) ${ }^{3}$. The author is "Georgius de regno dicto Sclavonije", thus originating from the south-western area of the Hungarian Kingdom. The vocabulary is structured according to 21 semantic fields and contains 1316 Hungarian words ${ }^{4}$.

Having the same source, the Nomenclature from Schlägl is also a copy, elaborated around the year 1405 after a document compiled several decades earlier. This vocabulary is of uttermost importance, as it represents the first attempt to compile a nomenclature starting from the Hungarian lexis instead of the Latin one. It comprises 2140 Hungarian words organized in 32 semantic fields ${ }^{5}$. This nomenclature is related to a Latin explanatory dictionary containing alphabetically ordered entries, entitled Hortularium (Prämonstratenser Stiftbibliothek, Cpl 156), written between 1420 and 1433 (see below, §2.3.2).

75 Latin names of plants and their correspondents in Hungarian were inserted on the white pages of a book edited in 1516 which belonged to the Library of the Reformed College in Cluj at the time it was discovered. It contains a total of 118 Hungarian words. These pages written around the year 1520 represent the first known attempt to compile a botanical vocabulary (Viski, 1905).

The Latin-German lexicon, the thematic appendix of a textbook written by the German humanist Ioannes Murmellius, had several editions, the one that is of utmost importance in our opinion being the 1526 edition, published in Krakow. This edition was used by a Hungarian scholar to create a LatinGerman-Hungarian lexicon: Lexicon Joannis Mvrmellii, in qvo Latina rerum uocabula in suas singula digesta classes, cum Germanica et Hungarica interpretatione Vt autem quodquis uocabulum facile inueniatur prestabit Index copiosus (Cracovia 1533). Found at the Franciscan monastery in Schwaz, the lexicon includes mainly nouns grouped according to semantic fields ${ }^{6}$. The number of Hungarian entries is about 4600 words, and the author occasionally provides explanations, such as: "Anisum - Oly fy ki embernek io szint ad" 'herb that gives a (healthy) colour to the face' (1453), "Cicercula - Tatárka ninczen magyar orsakban" 'buckwheat, it does not grow in Hungary' (1540), "Cereuisia saxonica - Saxoniabeli sŏr magyarnak nehez es segen ital” 'Saxon beer, a heavy and poor-quality drink for the Hungarians' (2180) (Szamota, 1896).

Gábor Pesti (? Pest, 1542 - 1550) is the author of a nomenclature that had six editions: Nomenclatvra Sex Lingvarvm Latine, Italice, Gallice, Bohemice, Hungarice, Germanice nouiter accessit... Per Gabrielem Pannonium Pesthinum (Vienna 1538, 1550, 1561, 1568). This is not an entirely original work, as it is based on a Latin-Italian-French-Czech-German dictionary edited in Nürnberg in 1531 (Vocabularius utilissimus quinque linguarum), used especially in German and Czech schools. Pesti compiled the dictionary for individual study (see also the 2013 reprint edition from Tinta Publishing House in Budapest).

\footnotetext{
${ }^{2}$ Actually in Bavarian dialect.

${ }^{3}$ Finály (1892), following a detailed analysis, reached the conclusion that the manuscript was elaborated at the end of the $14^{\text {th }}$ century, and stated that this copy was written at the beginning of the $15^{\text {th }}$ century.

${ }^{4}$ Examples: "humus - agag; collis - halm; colliculus - kis halom; kauerna - liuk; rus - mezeu; campus - idem".

${ }^{5}$ Here are a few examples from the $12^{\text {th }}$ group, which contains names for species of fish: "hal PIfcis - halaftho pifcina - kis hal pifcic ulus - toc dorica - viza vfo - harcha barbota - chompo tuica[?] - hal fereg 'sőreg' phin fturio - pofar pofardus - idem porand[us] - idem ftarpo - verian capito - chuca luceus - idem lumb[us]” (Zelliger, 2009, p. 237; see also Szamota, 1894).

${ }^{6}$ For instance: "De deo et rebus coelestibus - Istenrŏl es eghi dolgogrol - De temporibus - Ewdŏkrŏl - Terræ, Aquarum, et locorum uocabula Feldnek: visseknek es helŭknek neuek - De uarijs morborum generibus - Kulem fele betegsegrŏl - De piscibus - Hallakrol - De libris - Kŏnuegrŏl” (Szamota, 1896).
} 
The author's work is based on the Latin words and he also performed corrections in the Latin text. In the first section of the book, we find words grouped in 55 semantic fields, the nine sub-chapters of the second section include verbs and common phrases for the ones who want to make themselves understood in Hungarian or to engage in conversations about travels, horse-riding, missions, etc. (Gl.).

Fabricius Balázs Szikszai (c. 1530, Szikszó - 1576, Sárospatak ${ }^{7}$ ) is the author of a thematic nomenclature written for pedagogical purposes between 1561 and 1574, when he was a professor at the College of Sárospatak: Nomenclatura sev Dictionarium Latino-Vngaricvm per clarissimom D. Basilium Fabricium Szikszauianum. Szikszai's model was the work of Murmellius, which he enriched; his nomenclature comprises thus 9550 Hungarian words grouped in 113 semantic fields. The first edition of the dictionary, based on the copies made by students, was issued in Debrecen in 1590, after its author's death (Melich, 1907). As the College in Sárospatak had its own vineyard, orchard and garden, Szikszai introduced numerous notions related to viticulture, fruit growing and gardening. His work provides thus a very rich resource for researchers interested in the historical lexis of viticulture and gardening, and generally the lexis related to botany (Gombocz, 1936). The 1602 edition was enriched with a series of German equivalents whose author is unknown, yet it is certain that he was of Transylvanian Saxon origin. This trilingual edition was used in most schools until the year 1644 and it was re-edited in 1629 in Sibiu by Marcus Pistorium: Nomenclatvra seu dictionarivm Latino-Germanicum, ex varijs probatisque Autoribus collecta. Nunc denvo adiectum idioma Hungaricum, in usum discentium. Although the phrase "autoribus collecta" is included in the title, this book is actually a reprint of the 1602 edition of Szikszai's nomenclature (Melich, 1906, p. 428-429) . $^{8}$.

The first attempt to compile a Latin-Hungarian vocabulary of legal terms is Index verborum LatinoHungaricus printed in 1611 as an addendum to the most significant juridical work of the $16^{\text {th }}$ century: Werböczy István Decretvm Juris consuetudinarij, Inclyti Regni Hungarie et Transylvanie, azaz Magyar és Erdélyország törvénykönyve, Verböczi István által iratott 1514. eszten. Mostan Deakul es Magyarul, Egy hasznos Regestromal egyetemben uyobban ki boczatatot cum gratia et privilegio ${ }^{9}$. From the second half of the $15^{\text {th }}$ century we inherited a book of legal terms and phrases written by a notary public, János Magyi, who added Hungarian glosses (143 words in total) near the phrases specific to the Latin legal documents (Kertész, 2009), yet the work printed in 1611 is the first lexicographic work of this kind.

\subsection{Alphabetically-organized dictionariesc}

The first dictionaries organized alphabetically were issued in the $15^{\text {th }}$ century. For two of these dictionaries only fragments have been found, while another (the one from Brașov) can be regarded rather as a glossary ${ }^{10}$, yet since it was written on the territory of Transylvania it is of significant importance to us. These fragments of dictionaries and the first complete bilingual dictionaries are manuscripts. The first printed dictionary is a multilingual one. The greatest and most important lexicographic works include dictionaries that were issued in several editions, were used for a long time and had a great impact upon the development of modern Hungarian lexicography.

\subsubsection{Incomplete alphabetically-organized dictionaries}

The first such work is the Dictionary from Gyöngyös (Heves county, Hungary), elaborated between 1525 and 1556. The original was lost, but the copy made around the year 1560 was found tied to a copy of

\footnotetext{
${ }^{7}$ Both localities can be found today in the county of Borsod-Abaúj-Zemplén, Hungary.

${ }^{8}$ A trilingual vocabulary was also issued in Sibiu in 1709 (Vocabularium trilingve. Pro Usu Schole Cibiniensis recusum. Cibinii, Typis Reichardianis. Per Michaelem Hetzdörffer) based on the same edition, and the regionalisms indicate that the Hungarian scholar who contributed to the elaboration of this vocabulary originated from the Trei Scaune area (Covasna). (See also Fejér, 1995).

${ }^{9}$ We should mention that the first partial translation of Werbőczy's work dates from 1565 and was made by Balázs Weres, the notary public (notarius publicus) of the county of Bihor (Péter, 2012), and the language used in the legal system in Transylvania after 1541, during the Principality, was Hungarian.

${ }^{10}$ Although in our opinion this work is a glossary, in the literature of the field it is mentioned as a dictionary (Brassói szótártöredék).
} 
Emese Fazakas

Catholicon by Balbus of Ianua (1487, Veneția). The copyist intended to complete his work, as indicated by the fact that lines were also drawn on the last two blank pages (Melich, 1898), and he most probably copied from a complete work. The manuscript has 39 pages and contains 4617 Latin title-words with 10400 Hungarian correspondents. The last Latin word is cilones. This is actually an explanatory dictionary of the Latin language ${ }^{11}$, where possible etymologies are provided along with examples from ancient Latin authors, to which Hungarian equivalents were added, some of the explanations being also translated ${ }^{12}$. Moreover, the Hungarian author repeatedly uses synonyms or explanations: "Alutarius - szyw gyarto vel tymar; Carnificina: pelenger pyach: nyluan valo hely: holoth az hoharoktol Emberek olettethnek" (Melich, 1898). Thyese synonyms and explanations prove that the author was well aware of the fact that, by choosing only one correspondent in another language, it is sometimes difficult to render the meaning of the foreign word.

Around the year 1580, a Hungarian scholar elaborates a dictionary inspired by the editions of Calepinus' work ${ }^{13}$. This work was unfortunately lost and only two remaining fragments were found: the words between én 'I' and erö 'power' (Nagy, 1887). The novelty of this work is given, first of all, by the fact that entries were organized alphabetically and secondly by the fact that it is a fragment of a Hungarian-Latin dictionary, which means that the author initially had to elaborate a list of words in his mother tongue and arrange them alphabetically, with no previous model to follow. Not only does the author provide Latin correspondents for the 200 Hungarian headwords, but he also provides explanations and occasionally includes phrases (Bartók, 2017), exemplifying the area of usage of the respective word, as it is done in modern lexicographic works ${ }^{14}$. There are instances when explanations in Hungarian are provided: "Ep kybe semmy fogiatkozas ninch. Syncerus. syncere, et synceriter unde synceritas. Quasi sine carie, pro puro incorrupto immaculate contrarium" (Bartók, 2017, p. 32).

The Fragment from Braşov consists actually of Hungarian glosses noted in a Latin explanatory-etymological dictionary, organized alphabetically, elaborated after the model of Balbus of Ianua's Catholicon. The Hungarian correspondents (around 200) were introduced along the Latin ones by two different authors. Most entries were introduced between 1580 and 1590, while some of them were written later, at the beginning of the $17^{\text {th }}$ century. After performing a thorough analysis, Melich (1905) concluded that the authors of the glosses originated from the Ciuc area and the Trei Scaune county; it was possible to localize one of the authors because around the year 1617 he also added some personal notes ${ }^{15}$.

\subsubsection{Alphabetically organized dictionaries dating from the $15^{\text {th }}-18^{\text {th }}$ centuries}

The first nomenclature starting from the Hungarian lexis, the Nomenclature from Schlägl,was discovered bound together with an explanatory Latin dictionary with alphabetically organized entries entitled Hortularium (Prämonstratenser Stiftbibliothek, Cpl 156), written between 1420 and 1433. The Hungarian equivalents in Hortularium are not glosses and were not introduced in the dictionary subsequently, but

\footnotetext{
${ }^{11}$ The Latin explanations were copied not only from Catholicon, but also from several Latin dictionaries written in Italy, from Papias' Vocabularium and Calepinus' Dictionarium (one of the editions prior to 1544) (Melich, 1898).

${ }^{12}$ For instance: "Ascarotum, pauimentum picture arte elaboratum, sic dictum: quod uerri non debeat, i. purgari. Mesterseggel alkottatott: megh yrth pagymontom".

${ }^{13}$ Initially, Nagy (1887), following Szily's arguments (1886), believes that the author of the fragment was a Jesuit named István Szántó (Arator) who worked on the dictionary between 1580 and 1584. Yet Szilágyi (1891) claims that the author was the humanist and historian István Szamosközy, known as Zamosius (1570, Cluj - 1612, Alba Iulia), and this is the reason why this linguistic monument was subsequently entitled Szamosközi’s Fragment (Szamosközi-szótártöredék). If we consider the birth year of the Transylvanian historian, we can easily understand that at the time the dictionary was elaborated he must have been 10 years of age; consequently, either he was not the author or this manuscript was written at a later date.

${ }^{14}$ For instance: "Értelmes bezedewseg: charientismos; lat. urbanitas, lepos, sermonis venustas. Értelmes: Literæ gravissimis verbis atque sententiis. Cic. 10. 16. - Literæ magna verborum sen-ten tiarumque gravitate. 10. 12. - Literæ pleni consilii, summæque cum benevolentiæ, tum etiam prudentiæ. 9. 4. Att. - Prudentes et multi officii et consilii literæ. - Literæ amantissime et honorifioentissime scriptæ. - Literæ humanitatis sparsæ sale. Cic. 1., 10. Att." (Bartók, 2017, p. 33).

${ }^{15}$ The locality being Ojdula (the county of Covasna). Between the headwords Epiphania and Epystola, on the side, there is the following note: "Anno Domini 1617 die uero 14 Mensis Augusti. Az eoz aratatast (sic!) uegeztettel el, az poliani hataron" (Melich, 1905, p. 175) (= You had them plough the border towards Poian).
} 
written right after the Latin words by the same person; consequently this represents the first "modern" lexicographic work. From a dialectal point of view, the person who elaborated the dictionary originated most probably from the north-western part of the Hungarian Kingdom (Tóth, 2009b).

The first complete dictionary edited with alphabetically arranged entries was issued in 1585 in Lyon. The book is based on the work of lexicographer Ambrosius Calepinus, namely on an explanatory, etymological dictionary that also contained grammatical explanations regarding the Latin language. Since this work was regarded as significant, it was added a series of equivalents in several languages. The edition that includes the Hungarian correspondents is written in ten languages: Ambrosii Calepini Dictionarivm decem Lingvarum. Lyon, 1585 Vbi Latinis Dictionibvs Hebree, Grece, Gallice, Italice, Germanice, et Hispanice, itèmque nunc primó et Polonice, Vngarice atque Anglice adiecte sunt. We are aware of nine other editions of this version, of which the last was printed in 1627 in Basel. The Hungarian author is unknown, there were numerous attempts to establish his identity and Melich (1912), following a detailed phonetic and lexical analysis of the material, claimed that the Hungarian entries were most likely added by a person of Transylvanian origin.

Besides the monumental dictionaries, the most popular lexicographic works of the $16^{\text {th }}$ century were the ones in five languages. They were usually based on the Latin language, as in the case of Faustus Verancsics' dictionary (Vrančić, Verantius) (1551, Šibenik ${ }^{16}$ - 1617, Venice): Dictionarivm quinque nobilissimarvm Evrope Linguarvm, Latine, Italice, Germanice, Dalmatice et Vngarice (1595, Venice). Considering the fact that numerous lexicographic works were already in circulation at the time, it was supposed that Verancsics had several dictionaries as models for the elaboration of his list of headwords. However, Víg (2011) concludes that, although some parts indicate certain similarities, their number is quite insignificant and most probably the author relied on his own linguistic knowledge. When he encountered challenges and difficulties, he even made use of his own phrases and syntagms, using sources only occasionally, whenever he had the opportunity (Víg, 2011, p. 60). This dictionary is important from multiple perspectives: it is the first Croatian-Hungarian dictionary ${ }^{17}$ and it is also the first work that mentions the possible Slavic etymologies of certain Hungarian words. In the annexes, on pages 118-123, there is a Vocabula Dalmatica que Vngari sibi vsurparvnt, where 305 pairs of similar words are presented. On the last pages of the dictionary the author included religious texts in all five languages. Verancsics is regarded as the initiator of Croatian lexicography, as his work was used for subsequent selections. Thus, at the end of the $16^{\text {th }}$ century and the beginning of the $17^{\text {th }}$ century several Hungarian-Latin and Croatian-Latin dictionaries were issued and the Hungarian-Italian manuscript dictionary authored by Bernardino Baldi is also supposed to be a selection based on this work (Víg, 2011, p. 33).

The last significant work from the end of the $16^{\text {th }}$ century is a trilingual phraseological dictionary written by János Baranyai Decsi (1560, Decs ${ }^{18}$ - 1601, Tîrgu-Mureș), entitled Adagiorum Greco-LatinoUngaricorum Chiliades quinque (1598, Bártfa ${ }^{19}$ ). We should also mention here an early attempt to provide Hungarian equivalents for a series of proverbs, namely some glosses from the early $16^{\text {th }}$ century written in an incunabulum ${ }^{20}$. Another such attempt is represented by the glosses rendering Hungarian proverbs written between 1515 and 1540 by Tamás Pelei, a clergyman from Alba Iulia, who noted them in a 1508 Venice edition of Erasmus' collection. However, these are mere attempts at translation (Paczolay, 2001, p. 13). No further information is available with regard to other glosses or collections. Baranyai's phraseological dictionary seems to be unprecedented in the early period of Hungarian lexicography. In the introduction, the author enumerates the ancient and Medieval Latin sources, among which there are the names of Laertius, Teophrastos, Erasmus, and Gilbertus Cognatus. Baranyai uses the structure that was most popular in medieval collections, yet the aspect that speaks most eloquently of his activity as a

\footnotetext{
${ }^{16}$ Nowadays a locality in Croatia.

${ }^{17} \mathrm{He}$ actually used the words and variants of the dialect spoken in Dalmatia.

${ }^{18}$ Nowadays a locality in the county of Tolna, Hungary.

${ }^{19}$ Nowadays: Bardejov, Slovakia.

${ }^{20}$ Philelphus, Franciscus, Epistole, Jacobus Britannicus, Brescia, 1485.
} 
lexicographer is the fact that he does not translate the Latin and Greek proverbs, syntagms and phrases, but rather tries to provide their equivalents in Hungarian ${ }^{21}$. There are instances when the Latin proverb seems to be the translation of the Hungarian phrase: "Meße Buda sánta embernek - Procul Buda claudo" (see also Paczolay, 2001). This dictionary can be thus considered as one of the most valuable lexicographic works - to the above-mentioned argument one may add the fact that its study can shed light on the sayings and proverbs circulating in the $16^{\text {th }}$ century. Fortunately, this work has not sunk into oblivion; on the contrary, it was partially used by the authors of other dictionaries we shall mention later in this study, as well as by the authors of textbooks used in the $18^{\text {th }}$ and $19^{\text {th }}$ centuries.

Albert Szenczi Molnár (1574, Szenc ${ }^{22}$ - 1634, Cluj), basing his work on the best German and French dictionaries, managed to elaborate a Hungarian-Latin and Latin-Hungarian dictionary that was practical, relatively easy to use and comparable with any modern lexicographic work. Its 1604 Nürnberg edition, Dictionarivm Vngarico-latinvm and Dictionarivm Latinovngaricum, includes mainly words and phrases of common usage, but also contains numerous literary terms, art-related notions, terms pertaining to politics, social sciences, even anthroponyms, toponyms and hydronyms. Occasionally, the author inserts references to specific Hungarian aspects, but also to personal ones as well ${ }^{23}$. The title itself points to the importance of synonyms: "Synonyma quam plurima quæ inventati Vngaricæ hactenus ista commoditate destitutæ, quasi sylvam quandam vocabularum suppeditabunt", in the same manner in which modern dictionaries often specify synonyms according to the context. Besides these characteristics there are also stylisticsrelated mentions, such as: "eleganter, rectius, espresse" (Szathmári, 2007, p. 166). One can thus acquire a perspective upon the area of usage of certain terms, words and phrases. The edition from 1604 also includes a 5-page Latin-Hungarian vocabulary (on two columns) of rarely used legal terms. The last 30 pages list adjectival epithets used by Cicero ${ }^{24}$, their antonyms, the most frequently used adverbs and the verbs they relate with in specific phrases in certain contexts (Szathmári, 2007, p. 167). A new edition, enriched with Greek equivalents, was issued in Hanau in 1611 (Lexicon latino graco hungaricum), and in 1621 Szenczi Molnár re-edited the book in Heidelberg, adding a revised form of the Hungarian-Latin dictionary (Lexicon Latino-greco-Ungaricum - Dictionarium Ungarico-Latinum). This edition, besides the characteristics mentioned above, stands out among its contemporary lexicographic works as it includes several proverbs and sayings ${ }^{25}$ taken mainly from the work of János Baranyai Decsi, and enumerates the dialectal versions of certain words ${ }^{26}$ (Szathmári, 1999). Albert Szenczi Molnár’s lexicographic work also plays an important part in the process of standardization of the Hungarian language and in the development of modern lexicography.

One of the most significant dictionaries of the century is issued in 1708 in Löcse ${ }^{27}$ : Dictionarium Manuale Latino-Ungaricum et Ungarico-Latinum. Its author, Ferenc Pápai Páriz (1649, Dej - 1716, Aiud) was a philosopher, poet, doctor, professor at the Aiud College ${ }^{28}$, the author of several medical treaties in Latin and Hungarian, one of the first scholars to contribute to the development of a modern scientific approach. The first part of the dictionary (Dictionarium Manuale Latino-Ungaricum) is an original work for which Pápai Páriz consulted several dictionaries: Latin-French, Latin-English and LatinGerman, besides Comenius' works and the edition containing explanations and Hungarian equivalents of Marcus F. Wendelinus' phraseological collection, issued in Alba Iulia in 1646 and entitled Medulla

\footnotetext{
${ }^{21}$ For instance: "Tota erras via Item: Toto cælo errat Oly mefzfze vagy tŏlle, mint Mako Ierufalemtŏl” (= You are as far away (from something) as Makó [a locality in southern Hungary] is from Jerusalem).

${ }^{22}$ Nowadays Senec, Slovakia.

${ }^{23}$ For instance, in the case of Szenc, he specifies that this is his hometown.

${ }^{24}$ Eitheta, Antitheta et Adiuncta ex M. T. Ciceronis Collecta.

${ }^{25}$ The very title of the work points to the proverbs: "qui inspersa sunt usitatiora proverbia ungarica".

${ }^{26}$ For instance: "Leány - Lyán, Elvonom - Elvonyom; pro Schola dicant indifferenter Eskola, Iskola, Oskola" (Szathmári, 1999).

${ }^{27}$ Nowadays Levoča, Slovakia.

${ }^{28}$ See the fragment from the title of the dictionary (the 1767 edition): "Francisco Páriz Pápai Medicinae Doctore, Ejusdemque Facultatis in Celeberrima Academia Basileensi, Assessore; \& in Illustri Collegio Nagy-Enyediensi Professore Publico”.
} 
Latinitatis (Cser, 2006, p. 341). In the case of Hungarian equivalents, and especially when providing names for tools, household items, occupations and crafts, the author distinguishes between forms and variants that could somehow be regarded as "standard" 29 and dialectal words or variants. Moreover, Pápai Páriz marks the words that were no longer in use in the spoken language by the mention: antique. The second part of the dictionary represents an enriched edition of Szenczi Molnár's work, as also specified in the title: Dictionarium Hungarico-Latinum, olim magnâ curâ à Clarissimo viro Alberto Molnár Szentziensi collectum; Nunc vero revisum, \& aliquot vocabulorum, in Molnariano desideratorum, millibus Latinè redditis locupletatum. The second edition, issued in 1762 in Nagyszombat ${ }^{30}$, contains a contrastive phraseological addendum (Cser, 2006, p. 341).

Of all subsequent editions, the one issued in 1767 is of utmost importance. This edition was prepared by Péter Bod (1712, Cernatu de Sus - 1769, Ighiu). Bod-being inspired by Szenczi Molnár’s work-wrote a foreword in which he described the most important dictionaries issued and used until the first half of the $18^{\text {th }}$ century. As specified in the title (Dictionarium latino-bungaricum, succum et medullam purioris Latinitatis, ejusque genuinam in Ligvam Hungaricam conversionem... Francisco Páriz Pápai... Nunc vero proverbiis selectioribus interspersis, glossariolo voces Medii et Nostri avi, in Historiis, et Regnum Hungarie Decretis occurantes, insolentiores etc., explicante, Nominibus Propriis apud Hungaros usitatis, Nummorum Hungaricorum, Hebraicorum, Gracorum, Romanorum Tabellis, Siglarum Romanarum Expositione, aliisque necessariis et jucundis Accessionibus locupletatum intentione ac labore Petri Bod de F. Tsernáton, V.D. Ministri M. Igeniensis), the first part includes in its addenda a vocabulary of Latin proper names used in Hungary, a list of Latin abbreviations ${ }^{31}$ and several tables containing the conversion of units of measurement and coins ${ }^{32}$. The second part (Dictionarium hungarico-latinum, Olim magna cura a clarissimo viro Alberto Molnar Szentziensi collectum; Tandem Revisum et aliquot vocabulorum, in Molnariano desideratorum, millibus Latiné redditis locupletatum, Studio et vigiliis Francisci Páriz Pápai... Nunc vero Tam ex ejusdem Philoponi F. P. Pápai secundis curis ac Notationibus Mss. quam propriis et aliorum Observationibus, expletis qua defuerunt, amputatis qua superfuerunt, et vocibus quibusvis in suum ordinem redactis, volentiam usibus editum; Opera Petri Bod de F. Tsernáton, V. D. Ministri M. Igeniensis. Nove huic Editioni nunc primum solertia Typographi addita est Lingva Germanica) is enriched by Bod with German equivalents. Péter Bod was helped by József Benkő (1740, Brăduț - 1814, Aita Medie), who at that time was a student in Aiud, and a part of the words collected by Benkő were listed with their equivalents in Latin and German in the dictionary Addenda. This addendum includes only two pages, yet the list is extremely important as Benkő added words used in the dialects of the Székelys, as well as words originating from Romanian (for instance: armás cf. Rom. armaș 'an administrative function'; bálmos, cf. Rom. balmoş 'a sort of shepherds' food'; kaláka cf. Rom. clacă 'unpaid labour'; kompona cf. Rom. cumpănă 'balance'). The significance of this list resides in the fact that these words occur for the first time in a HungarianLatin(-German) dictionary and many are mentioned in writing for the very first time (Éder, 1978, p. 4045).

József Benkő continued to collect elements belonging to the Transylvanian lexis and was especially interested in botanical terms. Thus, in 1783, he published two dictionaries in Pozsony (Bratislava): the first one, Nomenclatura Botanica, is a Latin-Hungarian-German-French dictionary conceived according to Linné's botanical system, whereas the second, Nomina Vegetabilium, is a Latin-Hungarian-Romanian dictionary. In his preface to Nomina Vegetabilium, János Molnár-based on Benkő's letters-recounts the reasons for which the author chose to include the Romanian names of plants: the Romanians know

\footnotetext{
${ }^{29}$ Although one cannot yet speak of a standard language, for more than a century lexemes that were in the course of standardization could be distinguished from the dialectal ones.

${ }^{30}$ Nowadays Trnava, Slovakia.

31 "Characterum Romanorum atque Siglarum Expositio, faciens pro Lapidum, Monetarum Inscriptionibus interpretandis, ex variis Auctoribus collecta; Notæ Juris a Magone Collectæ; Signaturæ Philosophorum”.

32"Tabella nummorum hungaricorum; Tabella nummorum hebraicorum; Pecunia græcorum hungaricis comparata; Tabella nummorum græcorum; Signati romanorum nummi; Tabella pecuniæ romanæ; Ratio supputandi per sestertios”.
} 
medicinal plants very well and use them more skilfully than other peoples. He also mentions a Romanian doctor who, after practicing medicine in Bucharest, moved to Brașov and was of great help to him in the process of elaborating the dictionary, as were four Transylvanian Saxon apothecaries from Cluj and Braşov $^{33}$. These works are remarkable not only in the larger context of József Benkö's work, but also due to the fact that they represent an important stage in the development of the Hungarian botanical lexis and had a great influence upon the Romanian and Transylvanian Saxon botanical literature and lexicography in Transylvania (Éder, 1978, p. 33). We currently know of three collections, dictionaries elaborated based on Benkö's works: P. Sigerus Verzeichniss der Offizinellet Pflanzen (Siebenbürgische Quartalschrift, 1797); M. Fuss Verzeichniss der Pflanzen und der wichtigsten Synonymen (Archiv des Vereins für Sieb. Vaterlandsk, Hermanstadt 1846, III. 349-395); M. Fuss Alfabetische Zusammenstellung der ungarischen, wallachischen und deutschen Trivialnamen (Archiv des Vereins für Sieb. Vaterlandsk. Hermanstadt 1847, III. 177208). Of even greater importance is the influence of this author's work on the Romanian lexicography and terminology, as Nomina Vegetabilium is considered the first printed Romanian lexicographic work (Kelemen, 1957, p. 34). It was also used by the authors of Dictionarium Valachico-Latinum (1806, Buda) and Lexicon Budensis (1825, Buda). Sadly, József Benkö's work was not appreciated as such at that time by the Hungarian lexicographers and botanists (Éder, 1978, p. 33).

\section{Conclusions}

Our presentation of the beginnings of Hungarian lexicography was not intended to enumerate all the lexicographic works, which are quite numerous, even up to the $16^{\text {th }}$ century, but rather to indicate the most important glosses, vocabularies, nomenclatures, bilingual and multilingual dictionaries. We have thus presented early marginal or interlinear glosses starting from the $13^{\text {th }}$ century. One of the most important early linguistic sources in which the glosses are intertextual, distinguished from the Latin text by underlining, is included in Sermones Dominicales, a compilation of sermons written in the first half of the $15^{\text {th }}$ century. The vocabularies and nomenclatures we have discussed were written between the $14^{\text {th }}$ and the late $16^{\text {th }}$ century, most of them based on lists of Latin words grouped in semantic fields. The only work that was elaborated based on the Hungarian lexis is the Nomenclature from Schlägl, a copy drafted around 1405 after a document elaborated a few decades earlier. Among these vocabularies there are few that could be regarded as early attempts to elaborate specialized dictionaries, such as the botanical vocabulary written around the year 1526, Balázs Szikszai Fabricius' nomenclature, edited in 1590, and the first juridical Latin-Hungarian vocabulary written in 1611. Szikszai Fabricius' Nomenclature is the first work that had an impact upon the subsequent works and especially upon the development of the Transylvanian Saxons' lexicography. Starting with the $16^{\text {th }}$ century, there are several dictionaries in which headwords are organized alphabetically, yet the earliest ones were either left unfinished or incompletely preserved. The most representative dictionaries were written starting with the end of the $16^{\text {th }}$ century, most being multilingual and issued in several editions. Of these, Faustus Verancsics' dictionary marks the beginnings of Croatian lexicography and of Hungarian etymological dictionaries. János Baranyai Decsi's trilingual phraseological dictionary is remarked due to the Hungarian equivalents provided instead of translations for Latin and Greek proverbs, this material being used by Albert Szenczi Molnár and Péter Bod in the following centuries. The first practical, easy to use Hungarian-Latin and Latin-Hungarian dictionary, which also contains proper names, was elaborated by Albert Szenczi Molnár (1604), and one of the most important works is the complete edition re-written by Péter Bod (1769) after Ferenc Pápai Páriz' dictionary (1708). This was the most used lexicographic work for several decades. Our presentation ends

\footnotetext{
33 “A” Tudosításban az Iró, kinek ditséretes más illy munkája az első Szakafzban találtatik, elé-adja igyekezetének okát: mert az Oláhság igen isméri a' füveket, 's azokat hafzonra fordítván, más nemzeteket fellül halad. E' nevek özve-fzedésében fegitöje vólt Molnár Adány nevezetes Orvos Doktor; ki Brassóban végzé életét 1780-ban; minekutána majd 20. efztendeig vifelte az Orvosi hivatalt Bukereftben Havás al-földön (...) Egyéb fegittöje (...) Mauks Tobiás Kolozsvári nagy nevü Patikárius Úr, Weifskircher, Langedorf, és Birk Brassói Patikáros Urak (...) Tétettek ide olly Magyar fzózatok-is mellyek az elébbenyi munkában el-hagyattak" (see Éder, 1978, p. 32-33).
} 
with the botanical dictionaries elaborated by József Benkő, edited in 1783, which mark the beginnings of modern Hungarian lexicography and contributed to the development of the Romanian and Transylvanian Saxon lexicography.

\section{Bibliography}

Bartók, I. (2017). „Patvaros philosophusok, visszalkodo, maguk hanio böltsek”. Adalékok az 1530-1580 között keletkezett magyarországi glosszák, szójegyzékek és szótártöredékek kritikatörténeti vonatkozásaihoz, in "Irodalomtörténeti Közlemények”, 121, p. 23-60.

Benkő, L. (1958). A Marosvásárhelyi Sorok és Glosszák, in “Magyar Nyelv”, 54, p. 17-22.

Benkő, L. (1984). Megjegyzések az „Oxfordi glosszák”szavaihoz, in “Magyar Nyelv”, 80, p. 74-75.

Büky, B. (1984). Az „Oxfordi glosszák” szavairól, in “Magyar Nyelv”, 80, p. 71-73.

Cser, A. (2006). A magyar nyelvtudomány történetének áttekintése a kezdetektöl a 20. század elejéig, in Bajor, P., Kiefer, F., NáraySzabó, G. \& Pál, J. (eds), A magyar nyelv, Akadémiai Kiadó, Budapest, p. 335-351.

Éder, Z. (1978). Benkö József nyelvészeti munkássága és az Erdélyi Magyar Nyelvmüvelö Társaság, Akadémiai Kiadó, Budapest. Ernyey, J. \& Jakubovich, E. (1915). Két természetrajzi szójegyzék. I. „Ortus sanitatis”, in “Magyar Nyelv”, 11, p. 37-39, 80-83.

Farczády, E. \& Szabó T., A. (1957). A Marosvásárhelyi Sorok, Editura Academiei, București.

Fejér, R. (1995). Zur Geschichte der deutsch-ungarischen und ungarisch-deutschen Lexikographie. Von der Jahrhundertwende bis zum Ende des Zweiten Weltkrieges, Max Niemeyer Verlag, Tübingen.

Finály, H. (1892). A Besztercei Szószedet. Latin-magyar nyelvemlék a XV. századból, Értekezések a Nyelv- és Széptudomány Köréből XVI., Magyar Tudományos Akadémia, Budapest.

Gábriel, A. (1943). Egy XIII. századi magyar diák Párizsban, in "Egyetemes Philologiai Közlöny”, 67, p. 164-195.

Gáldi, L. (1938). Contributions à l'étude des lexiques latins-hongrois du moyen âge, Eötvös-füzetek XI, Eötvös Collegium volt Tagjainak Szövetsége, Budapest.

Gl. = Berrár, J. \& Károly, S. (eds) (1984). Régi magyar glosszárium. Szótárak, szójegyzékek és glosszák egyesitett szótára, Akadémiai Kiadó, Budapest.

Gombocz, E. (1936). A magyar botanika története, Magyar Tudományos Akadémia, Budapest.

Kelemen, B. (1957). Az új román-magyar nagyszótár szerkesztésének legfontosabb elvi és gyakorlati szempontjai, in "Nyelv- és Irodalomtudományi Közlemények", 1, p. 33-49.

Kertész, B. (2009). Magyi János formuláskönyve, in Madas, E. (ed.), „Latiatuc feleym...”. Magyar nyelvemlékek a kezdetektől a 16. század elejéig. Az Országos Széchényi Könyvtár kiállitása 2009. október 29-2010. február 21, Országos Széchényi Könyvtár, Budapest, p. 248-249.

Madas, E. (2009). Gyulafehérvári Sorok, in Madas, E. (ed.), „Latiatuc feleym...”. Magyar nyelvemlékek a kezdetektöl a 16. század elejéig. Az Országos Széchényi Könyvtár kiállitása 2009. október 29-2010. február 21, Országos Széchényi Könyvtár, Budapest, p. 228-229.

Melich, J. (1898). A gyöngyösi latin-magyar szótár-töredék, Magyar Tudományos Akadémia, Budapest.

Melich, J. (1905). A brassói latin-magyar szótár-töredék, Értekezések a Nyelv- és Széptudomány Köréből 19/4, Magyar Tudományos Akadémia, Budapest.

Melich, J. (1906). Szikszai Fabricius szójegyzéke 1590-böl, Magyar Tudományos Akadémia, Budapest.

Melich, J. (1907). A magyar szótárirodalom, Athenæum Irod. és Nyomdai Részvénytársulat, Budapest.

Melich, J. (1912). Calepinus latin-magyar szótára 1585-böl, Magyar Tudományos Akadémia, Budapest.

Melich, J. (1916). A Königsbergi Szójegyzék, in “Magyar Nyelv”, 12, p. 145-149, 263-265.

Mészöly, G. (1910). Jegyzetek a „Sermones dominicales” szótárához, in “Magyar Nyelv”, 6, p. 401-406.

Mezey, L. (1979). Deákság és Európa. Irodalmi müveltségünk alapvetésének vázlata, Akadémiai Kiadó, Budapest.

Mezey. L. (1981). Az Oxfordi Glosszák, in "Magyar Nyelv", 77, p. 372-376.

Nagy, Gy. (1887). Egy kéziratban maradt magyar-latin szótártöredék 1580 tájáról, in "Magyar Könyvszemle”, 12, p. $100-110$.

Paczolay, Gy. (2001). Baranyai Decsi Csimor János, a szóláskutató, in "Erdélyi Múzeum”, 3-4, p. 12-27.

Pálfi, M. (1907). Kolozsvári Glosszák, Nyelvészeti Füzetek 45. Athenæum Irodalmi és Nyomdai R. T., Budapest.

Péter, K. (2012). Werböczy anyanyelvi forditásainak tanulságai - értelmiségi feladatvállalás a 16. században, in "Történelmi Szemle", 3, p. 421-440.

Schönherr, Gy. (1904). A római Casanate-könyvtár Korvin-kódexe, in “Magyar Könyvszemle”, 29, p. 435-469.

Szabó T., A. (1943). Magyar növény-és gyógyszernevek a XVI. századból, in “Magyar Nyelv”, 39, p. 331-333, 391-397.

Szabó T., A. (1957). A Marosvásárhelyi Sorok és Glosszák, in "Magyar Nyelv”, 53, p. 335-351.

Szabó T., A. (1958). Magyar növény-és gyógyszernevek a XVI-XVIII. századból, in "Studia Universitatum Victor Babeș et Bolyai", III (6), series IV., fasc. 1, p. 161-177.

Szamota, I. (1894). A Schlägli magyar szójegyzék a XV. század első nyegyedéböl, Akadémiai Kiadó, Budapest.

Szamota, I. (1896). A Murmelius-féle latin-magyar szójegyzék 1533-ból, Értekezések a Nyelv- és Széptudományok Köréből, Magyar Tudományos Akadémia, Budapest. 
Szathmári, I. (1999). Személy-és folldrajzi nevek Szenczi Molnár Albert 1621-i magyar-latin szótárában, in "Névtani Értesíto", 21, p. 270-274.

Szathmári, I. (2007). Mennyiben szolgálták Szenczi Molnár Albert szótárai a magyar irodalmi nyelv (sztenderd) létrejöttét?, in "Magyar Nyelvőr", 31, p. 163-172.

Szilágyi, S. (1891). Szamosközy István szótára, in “Magyar Könyvszemle”, 16, p. 100-110.

Szily, K. (1886). Ki volt Calepinus magyar tolmácsa?, Értekezések a Nyelv- és Széptudományok Köréből, Magyar Tudományos Akadémia, Budapest.

Tóth, P. (2009a). Sermones Dominicales, in Madas, E. (ed.), „Latiatuc feleym...”. Magyar nyelvemlékek a kezdetektól a 16. század elejéig. Az Országos Széchényi Könyvtár kiállitása 2009. október 29-2010. február 21, Országos Széchényi Könyvtár, Budapest, p. 244-245.

Tóth, P. (2009b). Schlägli Hortularium, in Madas, E. (ed.), „Latiatuc feleym...”. Magyar nyelvemlékek a kezdetektöl a 16. század elejéig. Az Országos Széchényi Könyvtár kiállitása 2009. október 29-2010. február 21, Országos Széchényi Könyvtár, Budapest, p. 238-239.

Varjú, E. (1899). A gyulafejérvári kódex, in "Akadémiai Értesíto"”, 10, p. 16-25.

Víg, I. (2011). Verancsics Faustus Dictionariuma a korabeli európai kontextusban, Tinta Kiadó, Budapest.

Viski, K. (1905). Nyelvemlék a kolozsvári református kollégium könyvtárában, in “Magyar Nyelvőr, 34, p. 200-2003.

Viski, K. (1906). Tordai Tamás lapszéli jegyzetei a XVI. századból, in “Magyar Nyelvőr”, 35, p. 222-224.

Vízkelety, A. (2009). Irodalmak útban a pergamen felé, in Madas, E. (ed.), „Latiatucfeleym...”. Magyar nyelvemlékek a kezdetektől a 16. század elejéig. Az Országos Széchényi Könyvtár kiállitása 2009. október 29-2010. február 21, Országos Széchényi Könyvtár, Budapest, p. 79-93.

Zelliger, E. (2009). Schlägli szójegyzék, in Madas, E. (ed.), „Latiatuc feleym...”. Magyar nyelvemlékek a kezdetektöl a 16. század elejéig. Az Országos Széchényi Könyvtár kiállitása 2009. október 29-2010. február 21, Országos Széchényi Könyvtár, Budapest, p. 237.

Zolnai, Gy. (1910). A Budapesti és Németújvári Glosszák, in “Magyar Nyelvőr”, 19, p. 460-474. 